\title{
Value Congruence in the Egyptian Hotel Industry: The Role of Transformational and Transactional Leadership
}

\section{Ibrahim Elshaer}

Lecturer of Hotel Studies, Faculty of Tourism and Hotels, Suez Canal University-Egypt

\author{
Othman Elsawi
}

Lecturer of Hotel Studies, Faculty of Tourism and Hotels, Suez Canal University-Egypt

\begin{abstract}
This paper aims at investigating leader-follower value congruence in the Egyptian hotel industry. The impact of employees' cultural values (power distance, uncertainty avoidance, and individualism vs. collectivism) on their perception of the appropriate leadership style (transactional and transformational leadership style) was theoretically discussed and empirically tested. To date, no studies have sought to link these two constructs (leadership styles and employees' cultural values), and therefore no model exists to theoretically and/or practically link these concepts within the hospitality industry in Egypt, a gap this paper aims to fill. A structured questionnaire derived from an extensive literature review was completed by employees in five star hotels. A total of 500 responses were obtained. One hundred uncompleted questionnaires were eliminated leaving 400 usable questionnaires with a response rate of $80 \%$. Reliability of the variables was analyzed by employing Cronbach's alpha method, exploratory factor analysis (EFA) was used to test the dimensional structure of the study variables, and finally, Path analysis in structural equation modeling (SEM) was conducted to assess the research hypotheses. The results of the current study give an evidence that might help hotel managers to adopt certain leadership styles to fit with the employees' cultural values. The implications of the current study results were then discussed and interpreted.
\end{abstract}

Keywords: Value Congruence, Leadership Style, Hotel Industry, Structure Equation Modeling.

\section{Introduction}

Value congruence can be defined as the compatibility of employees' work values and those of other three different categories, namely leaders, co-workers, and the organization (Edwards and Cable, 2009).Value congruence yields favorable outcomes which are relevant to employees and organizations as well, like decreasing turnover costs, and promoting extra-role behaviors related to employee's positive attitudes (Riketta,2005). Value congruence between leaders and their followers is essential for leadership effectiveness (Jung and Avolio, 2000). Studying leader-follower value congruence in the hospitality industry is important, as leadership skills may achieve the best use of human resources and enable hospitality organizations to deal with environmental pressure as well (Erkutlu and Chafra, 2006).

Leaders must pay attention to the national culture within the workplace as culture affects the values and attitudes of the work group. Consequently, it can shape their perceptions regarding work environment and its components including leadership (Hofstede, 1991). This threatens the universality of a specific leadership style across cultures (Jones, 2004). Relatively Hofstede (1980) determined four cultural dimensions reflect employees' values called (power distance, uncertainty avoidance, individualism vs. collectivism, and masculinity vs. femininity). In light of these dimensions, people from different cultures can assess the appropriateness of every leadership style.

Although numerous theories have been developed to explain leadership effectiveness, much of these theories have American bias. This calls for manifesting them in other cultures (Jackson, 2011). For Eastern countries, culture may affect work values and attitudes of employees in a way that differentiate results drawn from Western studies (Yu and Miller, 2005). Transformational and transactional theory of leadership seems to be more popular. Although many researches tested this theory in different cultures, emerging nations have been paid little attention. There is a lack of transformational-transactional studies in Egypt (Shahin and Wright, 2004). So far, no studies have sought to link the two constructs (leadership styles and employees' cultural values within the hospitality industry in Egypt), and therefore no model exists to theoretically and/or practically link these two constructs, a gap this paper aims to fill. 


\section{Leadership Theories}

Traits theory firstly attempted to explain leadership effectiveness. The search for leadership traits began in the 1930s. It depended on isolating some traits that differentiate leaders from non-leaders (Jones and George, 2007). With regard to this notion, hundreds of studies resulted in a number of dead-ends traits that appeared to be related to effective leadership like (self-confidence, Initiative, Intelligence, and belief in one's actions) (Mullins, 2006).

Traits theory failed alone to describe leadership effectiveness, as it couldn't determine a consistent set of traits differentiating leaders from non-leaders (Mullins, 2006 ; Sinha, 2008). This led researchers to look for other ways describing effective leadership requirements (George and Jones, 2008).

In1940s and 1950s, the behavioral theory (approach) which depends on what leaders actually do instead of their traits was a new trend in leadership research. The behavioral theory involved many studies, the most comprehensive one was Ohio state university study which divided leadership behaviors into two types: initiating structure and consideration (Johns and Saks, 2005 ; Tsai, 2008). Initiating structure refers to leader's tendency to structure the roles of their followers for achieving work goals through assigning particular tasks to group members, expecting followers to perform according to agreed-upon standards, and meeting deadlines. Consideration is reflected by behaviors like mutual respect for followers' ideas and feeling, helping them to solve personal problems, and being friendly and theoryable (Yukl, 2010).

However, behavioral theory hadn't the ability to identify consistent relationships between patterns of leadership behaviors and effective performance. The fruitless search for a universal theory to leadership effectiveness made researchers reformulate their assumptions, consequently, they developed the contingency theory of leadership (Strogh et al., 2002 ; Robbins and DeCenzo, 2004).

In 1970s, the contingency theory of leadership proposed that the appropriate leadership behavior varies according to work context. Its goal was to isolate key situational factors and specify how they interact in order to determine the most suitable leadership behavior (Griffin, 2000). In this context, many theories were developed, like path-goal theory and situational theory of leadership (Moorhead and Griffin, 1992).

Although it seemed desirable for this type of theories to involve many relevant aspects of the work situation, this made theories difficult to be empirically tested (Yukl, 2010).

\section{Transformational and transactional leadership theory}

Burns (1978) introduced the paradigm of transformational leader as opposed to transactional leader. This theory attempted to create a better understanding of leadership effectiveness compared to the other theories (Bass et al., 2003).

\section{Transformational Leadership}

Motivating followers to act beyond expectations by communicating them the importance of tasks outcomes, this makes them transcend their self-interest for the sake of the property. Transformational leadership consists of four patterns of behavior called 4 I's: (1) Idealized influence (charisma), (2)Intellectual stimulation, (3) Inspirational motivation, and (4) Individualized consideration (Bass, 1985)

Idealized influence: Is reflected by behaviors that encourage followers to use their leaders as role models. Achieving idealized influence requires creating values that inspire, provide meaning for, and instill a sense of purpose in the followers. To demonstrate idealized influence, leaders need emotional stability and control for helping them to overcome inner conflicts and believe in their abilities to master their own destinies (Sarros and Santora, 2001). Idealized influence results in achieving follower's self-esteem and confidence via positive reinforcement and continuous encouragement of their capacities to work successfully (Bass and Riggio, 2006).

Intellectual stimulation: Involves encouraging followers to: Use new ways to solve old dilemmas, employ reasoning, rationality and evidence rather than un-supported opinions, and accept challenge and creativity in the job (Gill et al., 2006).

Inspirational motivation: concentrates on leveraging follower's consciousness and encouraging their commitment regarding organization's mission and vision. Inspiring followers helps actively in drawing out the best in them conditioned by setting high standards and using a simple method to communicate it (Kouzes and Posner, 2003). 
Individualized consideration: relates to paying attention to follower's needs and fostering learning experience through providing feedback (Bass, 2000).

\section{Transactional Leadership}

The notion of this style is the exchange process between leaders and their followers in order to motivate follower's adherence to leader's requests and organizational rules. It includes management by exceptions and contingent reward (Burns, 1978).

Management by exceptions: involves looking for mistakes and enforcing rules to avoid it. While, the contingent reward is a positive reciprocal relationship between leaders and followers who exchange ideas and skills in the pursuit of organization's goals and followers needs. Leaders who use contingent rewards tend to be directive to get the job done.

\section{Value congruence}

Both positive and negative results can be emerged from employees' appraisal of the work environment including leadership style (Newman and Nollen, 1996). Values are acquired from the culture where individuals were reared. They can determine what's right or wrong, important or un-important. Consequently, values assist in directing human behavior, as illustrated in figure 1.

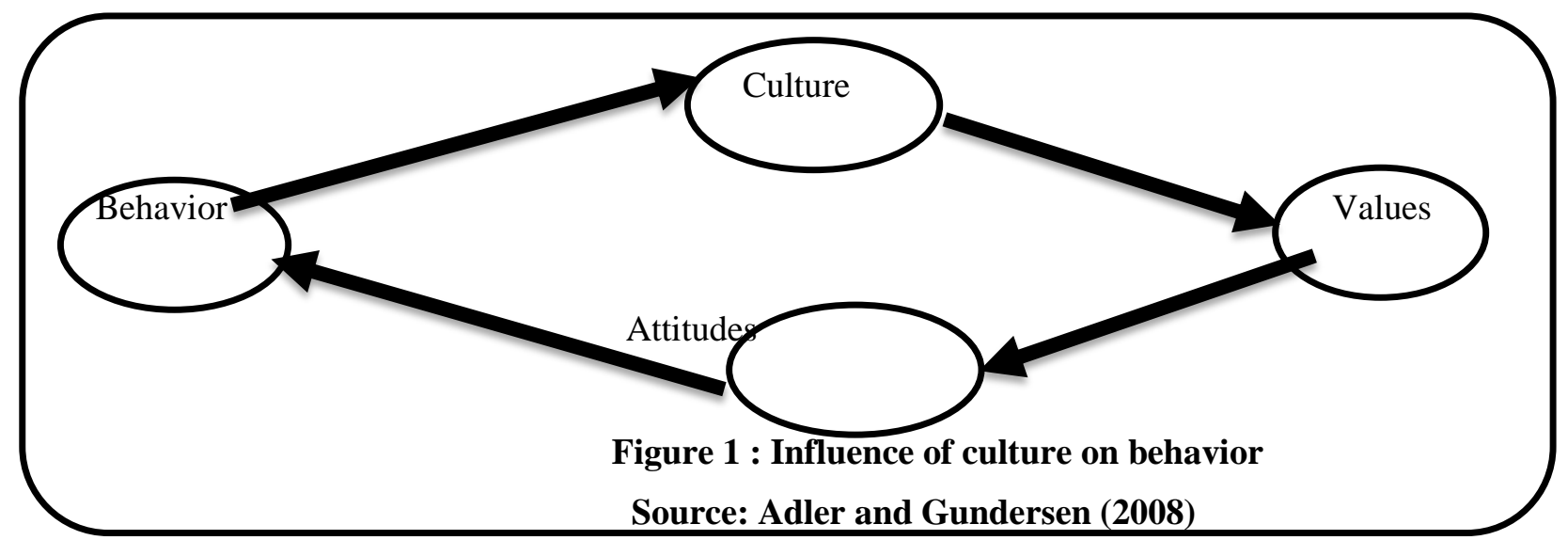

Values affect various outcomes via value congruence, which means the extent to which individuals share the same values, it also includes some types, like alignment of values between followers and their leaders (Leader-follower fit). Leadership style is the tool used to achieve value congruence (Meglino et al., 1991). Employees are affected by their leaders if they share their values. Value congruence is said to be the mechanism that influences organizational outcomes (Kalliath et al., 1999)

\section{Hofstede cultural dimensions model}

Hofstede collected his data depending on more than 116000 respondents from more than 70 different countries, making this study the largest organizationally based one ever conducted (Luthans and Doh, 2009). The notion of difference in values and beliefs regarding work goals was the base of this model which considered that any culture positioning on the following dimensions: Power distance, Uncertainty avoidance, Individualism Vs. Collectivism, and Masculinity Vs. Femininity

Power distance relates to the preferred way to deal with inequality among people within the culture. In high power distance countries, there is an emphasis on hierarchy, disliking work and tendency to avoid it (Hofstede, 1980). Consequently, managers believe that authoritarian style: that depends on forcing followers to perform under close supervision is the best leadership style for high power distance countries (Cullen and Parboteeah, 2005). As a result of the previous discussion, the following hypotheses are introduced:

H1: There is a relationship between Low power distance employees and transformational leadership style;

H2: There is a relationship between High power distance employees and transformational leadership style;

H3: There is a relationship between Low power distance employees and transactional leadership style;

H4: There is a relationship between High power distance employees and transactional leadership style. 
Uncertainty avoidance concentrates on the level of tolerance for ambiguity. Order and predictability are paramount for high uncertainty avoidance cultures. People in such a culture consider risky situations as harmful and stressful (Hofstede, 1980), thus they prefer task-oriented leadership: that includes giving explicit directions to followers and reducing vagueness regarding job assignments. In low uncertainty avoidance cultures, more flexibility and choices in the job are desirable (non-directive leadership) (Cullen and Parboteeah, 2005). According to uncertainty avoidance requirements, it can be hypothesized that:

H5: There is a relationship between employee with high uncertainty avoidance and transformational leadership style;

H6: There is a relationship between employee with low uncertainty avoidance and transformational leadership style;

H7: There is a relationship between employee with high uncertainty avoidance and transactional leadership style;

H8: There is a relationship between employee with low uncertainty avoidance and transactional leadership style.

Individualism Vs. Collectivism reflects the relationship between individuals and collectivity that dominates the society. In individualistic societies the ties between individuals are loose, and individuals are expected to look

after themselves. Individualistic cultures place a great emphasis on individual initiative, rights, and achievement. Collectivistic cultures form a tight social framework where people differentiate between ingroups and out-groups and provide loyalty to in-groups expecting support from them (Hofstede, 1980). This lead to hypothesize that:

H9: There is a relationship between collectivistic employees and transformational leadership style;

H10: There is a relationship between individualistic employees and transformational leadership style;

H11: There is a relationship between collectivistic employees and transactional leadership style;

H12: There is a relationship between individualistic employees and transactional leadership style.

\section{Research methodology}

\section{Data collection}

Data was obtained from surveying employees working in non-managerial positions in 72 five-star hotels located in Sharm El Sheikh and Red Sea regions in Egypt for achieving value congruence via investigating the impact of Hofstede cultural dimensions (Power distance, Uncertainty avoidance, and Individualism Vs. Collectivism) on the leadership style (transformational, and transactional). A total of 500 responses were obtained. One hundred uncompleted questionnaires were eliminated leaving 400 usable questionnaires with a response rate of $80 \%$. The questionnaire was pre-tested by interviewing 20 employees and ten academic researchers. Some amendments to the questionnaire were done to enhance its clarity and to remove some duplicated variables. The variables' reliability was analyzed by Cronbach's alpha method; exploratory factor analysis (EFA) was used to test the dimensional structure of the study variables, and finally, structural equation modeling (SEM) was conducted to support/reject the research hypotheses.

\section{Respondent characteristics}

Two hundred and eighty (280) responses were received from employees working in 5 star hotels in Sharm El Sheikh region with a percentage of $56 \%$, while 220 responses were received from employees working in 5 star hotels in Red Sea region with a percentage of $44 \%$. One hundred uncompleted questionnaires were eliminated leaving a response rate of $80 \%$. See table (1).

Table (1) : Responses according to hotel category and area

\begin{tabular}{|c|c|c|c|c|c|}
\hline Area & $\begin{array}{c}\text { Hotel } \\
\text { category }\end{array}$ & $\begin{array}{c}\text { Total } \\
\text { number }\end{array}$ & $\begin{array}{c}\text { Total } \\
\text { questionnaires } \\
\text { received }\end{array}$ & Uncompleted & $\begin{array}{c}\text { Total valid } \\
\text { responses }\end{array}$ \\
\hline $\begin{array}{c}\text { Sharm } \\
\text { Elsheikh }\end{array}$ & $5 \mathrm{star}$ & 56 & 280 & 60 & 220 \\
\hline
\end{tabular}




\begin{tabular}{|c|c|c|c|c|c|}
\hline Red Sea & 5 star & 58 & 220 & 40 & 190 \\
\hline Total & & 114 & 500 & 100 & $400(80 \%)$ \\
\hline
\end{tabular}

After preliminary analysis of the current study responses, and following Hofstede $(1980,1985)$ way to classify the culture values, we found that $53.75 \%$ of the sample has low power distance, $51.25 \%$ has high -uncertainty avoidance and finally $53 \%$ are collectivism vs $47 \%$ individualism. (See Table 2 ).

Table (2) : Hofstede_values in the study sample

\begin{tabular}{|c|c|c|c|c|c|}
\hline \multicolumn{2}{|c|}{ POWER DISTANCE } & \multicolumn{2}{|c|}{ UNCERTAINTY AVOIDANCE } & \multicolumn{2}{c|}{ INDIVIDUALISM/ COLLECTIVISM } \\
\hline $\begin{array}{c}\text { high-power } \\
\text { distance }\end{array}$ & $\begin{array}{c}\text { low-power } \\
\text { distance }\end{array}$ & $\begin{array}{c}\text { high-uncertainty } \\
\text { avoidance }\end{array}$ & $\begin{array}{c}\text { low-uncertainty } \\
\text { avoidance }\end{array}$ & individualism & Collectivism \\
\hline 185 & 215 & 205 & 195 & 188 & 212 \\
\hline $46.25 \%$ & $53.75 \%$ & 51.25 & $48.75 \%$ & $47 \%$ & $53 \%$ \\
\hline
\end{tabular}

The Majority of responses were male employees (86\%). The age group of 25 to 35 years was the largest percentage in the study sample (70.4\%). Employees who had worked at their hotel for 1 to 4 years, represented $45.6 \%$ of the total.

Tests for dimensionality, and reliability.

The results of the EFA with principal components as the factor extraction technique and Varimax orthogonal rotation to get the best solution can be visually seen in Table (3) to provide an evidence and confidence to the study results.

\section{Results of EFA for leadership styles}

The first exploratory factor analysis generated a six-factor solution for the leadership style construct: four factors for the transformational leadership style (Idealized Influence, Inspirational Motivation, Intellectual Stimulation, and Individualized Consideration) and two factors for the transactional leadership style (Contingent Reward, and Management-by-exception) (see table 3). A six-factor structure is attained with an eigenvalue more than 1 , and the extracted factors account for $88.14 \%$. Bartlett's test of sphericity is significant, which refers to a non-zero correlation between the 19 variables that measure leadership style and a high level of homogeneity between the investigated items (Field, 2006). Bartlett's test of sphericity indicates a Chi-square of 5795.3840, with df of 171 and significance level less than 0.001 . The overall measure of sampling adequacy (KMO) is 0.936 , this value is higher than 0.5 recommended by Field (2006) and Hair et al., (2006).

Table (3): Statistical summary: Factor analysis (with the Principal component as an extraction method), and reliability analysis for the study constructs.

\begin{tabular}{|c|c|c|c|c|c|c|c|c|c|}
\hline Factors and Variables & \multicolumn{7}{|c|}{ Factor Components \&Loading } & \multicolumn{2}{|c|}{ Reliability } \\
\hline TRANSFORMATIONAL & & 1 & 2 & 3 & 4 & 5 & 6 & CITC & $\alpha$ \\
\hline Idealized Influence & & & & & & & \\
\hline
\end{tabular}




\begin{tabular}{|c|c|c|c|c|c|c|c|}
\hline $\begin{array}{l}\text { My manager makes others feel good to } \\
\text { be around him. }\end{array}$ & .779 & & & & & .852 & \\
\hline I have complete faith in my manager. & .795 & & & & & .883 & \\
\hline $\begin{array}{l}\text { I am proud to be associated with my } \\
\text { manager. }\end{array}$ & .792 & & & & & .871 & \\
\hline Inspirational Motivation & & & & & & & .926 \\
\hline $\begin{array}{c}\text { My manager expresses with a few } \\
\text { simple words what he could and should } \\
\text { do. }\end{array}$ & & .837 & & & & .850 & \\
\hline $\begin{array}{l}\text { I would still keep working in the hotel, } \\
\text { even if this would be more difficult. }\end{array}$ & & .823 & & & & .863 & \\
\hline $\begin{array}{c}\text { My manager provides appealing images } \\
\text { about what we can do. }\end{array}$ & & .802 & & & & .850 & \\
\hline $\begin{array}{l}\text { My manager helps others find meaning } \\
\text { in their work. }\end{array}$ & & .809 & & & & .840 & \\
\hline Intellectual Stimulation & & & & & & & .931 \\
\hline $\begin{array}{l}\text { Managers enable us to think about old } \\
\text { problems in new ways. }\end{array}$ & & & .816 & & & .876 & \\
\hline $\begin{array}{l}\text { Managers provide us with new ways of } \\
\text { looking at puzzling things. }\end{array}$ & & & .817 & & & .850 & \\
\hline $\begin{array}{l}\text { Managers can get others to rethink ideas } \\
\text { that they had never questioned before. }\end{array}$ & & & .826 & & & .847 & \\
\hline Individualized Consideration & & & & & & & .914 \\
\hline $\begin{array}{c}\text { My manager helps me to develop } \\
\text { myself. }\end{array}$ & & & & .843 & & .767 & \\
\hline $\begin{array}{c}\text { My manager lets us know how we are } \\
\text { doing. }\end{array}$ & & & & .794 & & .840 & \\
\hline $\begin{array}{l}\text { Managers give personal attention to } \\
\text { employees who seem rejected. }\end{array}$ & & & & .802 & & .878 & \\
\hline \multicolumn{8}{|c|}{ TRANSACTIONAL } \\
\hline Contingent Reward & & & & & & & .951 \\
\hline $\begin{array}{l}\text { Managers tell others what to do to be } \\
\text { rewarded for their work. }\end{array}$ & & & & & .814 & .876 & \\
\hline $\begin{array}{l}\text { Managers provide recognition/rewards } \\
\text { when others reach their goals. }\end{array}$ & & & & & .795 & .890 & \\
\hline $\begin{array}{l}\text { Managers pay attention to what others } \\
\text { can get for what they accomplish. }\end{array}$ & & & & & .819 & .920 & \\
\hline
\end{tabular}




\begin{tabular}{|c|c|c|c|c|c|c|c|c|}
\hline Management-by-exception & & & & & & & & .949 \\
\hline $\begin{array}{l}\text { Managers are satisfied when others meet } \\
\text { agreed-upon standards. }\end{array}$ & & & & & & .780 & .888 & \\
\hline $\begin{array}{l}\text { As long as things are working, managers } \\
\text { do not try to change anything. }\end{array}$ & & & & & & .762 & .897 & \\
\hline $\begin{array}{l}\text { Managers tell others the standards they } \\
\text { have to know to carry out their work. }\end{array}$ & & & & & & .751 & .893 & \\
\hline$\%$ of Cumulative variance & 18.7 & 33.09 & 47.39 & 61.55 & 75.10 & 88.14 & & \\
\hline
\end{tabular}

Kaiser-Meyer-Olkin (KMO) Measure Sampling Adequacy = 0.936; Bartlett test of sphericity = 5795.3840 with df 171; Bartlett test, significanc $=\mathbf{0 . 0 0 0}$. Note: CITC $=$ Corrected Item-Total correlations, $\alpha=$ Cronbach's Alpha

\begin{tabular}{|c|c|c|c|c|c|}
\hline \multirow[t]{2}{*}{ Factors and Variables } & \multicolumn{3}{|c|}{ Factor Components \&Loading } & \multicolumn{2}{|c|}{ Reliability } \\
\hline & 1 & 2 & 3 & CITC & $\mathbf{A}$ \\
\hline POWER DISTANCE & & & & & .937 \\
\hline I am afraid to disagree with their managers & & & .873 & .723 & \\
\hline $\begin{array}{c}\text { My manager tends to take decisions in an autocratic or } \\
\text { persuasive/paternalistic way }\end{array}$ & & & .803 & .802 & \\
\hline $\begin{array}{l}\text { I prefer anything but a consultative style of decision- making in } \\
\text { my boss: that is for an autocratic, a persuasive/paternalistic, or a } \\
\text { democratic style }\end{array}$ & & & .690 & .587 & \\
\hline UNCERTAINTY AVOIDANCE & & & & & .954 \\
\hline $\begin{array}{c}\text { Company rules should not be broken even when I think that they } \\
\text { are not in the company's best interest }\end{array}$ & .751 & & & .738 & \\
\hline $\begin{array}{l}\text { I will continue with the company for two years at most or from } \\
\text { two to five years }\end{array}$ & .794 & & & .864 & \\
\hline $\begin{array}{l}\text { I feel nervous or tense at work when I have a lot of work to be } \\
\text { done }\end{array}$ & .755 & & & .826 & \\
\hline $\begin{array}{l}\text { It is important to have job requirements and instructions spelled } \\
\text { out in detail so that I always know what I have to do }\end{array}$ & .872 & & & .930 & \\
\hline Individualism vs. Collectivism & & & & & .950 \\
\hline $\begin{array}{c}\text { Organization motivation strategies are based on performance not } \\
\text { experience }\end{array}$ & & .605 & & 688 & \\
\hline I prefer not to cooperate with my colleagues in the organization & & .771 & & .864 & \\
\hline I prefer doing my duties without any help from others & & .653 & & .748 & \\
\hline Willing to work overtime in the organization & & .868 & & .871 & \\
\hline Not fully use my skills and abilities on the job & & .860 & & .868 & \\
\hline
\end{tabular}




\begin{tabular}{|c|c|c|c|c|c|}
\hline Get the recognition I deserve when I do a good job & & .710 & & .814 & \\
\hline Have considerable freedom to adopt my own theory to the job & & .652 & & .912 & \\
\hline $\begin{array}{l}\text { Have training opportunity to improve my skills and knowledge or } \\
\text { to learn new skills and knowledge }\end{array}$ & & .651 & & .824 & \\
\hline$\%$ of Cumulative variance & 34.069 & 62.18 & 78.31 & & \\
\hline \multicolumn{6}{|c|}{$\begin{array}{l}\text { Kaiser-Meyer-Olkin }(\text { KMO) Measure Sampling Adequacy = 0.881; Bartlett test of sphericity = } 8650.664 \text { with df } 171 \text {; Bartlett } \\
\text { test, significanc }=\mathbf{0 . 0 0 0} \text {. Note: CITC = Corrected Item-Total correlations, } \alpha=\text { Cronbach's Alpha }\end{array}$} \\
\hline
\end{tabular}

Overall, these statistics matched the fundamental requirements for factor analysis (Hair et al., 2006). Factor loadings for the 19 leadership variables were all more than 0.6 on their own factors, as recommended by Hair et al., (2006). None of the 19 items was dropped. More specifically, the transformational leadership style consisted of four dimensions. The factor loading for the retained items are as following: Idealized Influence $(0.779,0.795$, and 0.792 respectively), Inspirational Motivation $(0.837,0.823,0.802$, and 0.809 respectively), Intellectual Stimulation $(0.816,0.817$, and 0.826 respectively), and Individualized Consideration $(0.843, .0794$, and 802 respectively) and two factors for the transactional leadership style: Contingent Reward $(0.814,0.795$, and 0.819 respectively), and Management-by-exception( $(0.780,0.762$, and 0.751 respectively) (See table 3 ).

\section{Results of EFA for Hofstede cultural values}

The second exploratory factor analysis generated a three-factor solution for Hofstede cultural values: power distance, uncertainty avoidance, and individualism vs collectivism (See table 3). A three-factor structure is attained employing the criterion of an eigenvalue more than 1, and the extracted factors account for $78.31 \%$. Bartlett's test of sphericity is significant, referring to a non-zero correlation between the 15 variables that measure Hofstede cultural values and a high level of homogeneity between the investigated items (Field, 2006). Bartlett's test of sphericity indicates a Chi-square of 8650.664, with df of 171 and significance level of 0.000 . The overall measure of sampling adequacy (KMO) is 0.881 ; this value is higher than 0.5 that recommended by Field (2006) and Hair et al., (2006). Overall, these statistics matched the fundamental requirements for factor analysis (Hair et al., 2006). Factor loadings for the 15 Hofstede cultural variables were all more than 0.6 on their own factors, as recommended by Hair et al., (2006). None of the 15 items was dropped. More specifically, the factor loading for the retained items are as follows: power distance ( $0.873,0.803$, and 0.690 respectively), uncertainty avoidance $(0.751,0.794,0.755$, and 0.872 respectively), and individualism vs collectivism $(0.605,0.771,0.653,0.868,0.860,0.710,0.652$, and 0.651 respectively ) (see table 3).

\section{Test of reliability}

Composite Cronbach Alpha values for all dimensions that measure transformational leadership styles (Idealized Influence, Inspirational Motivation, Intellectual Stimulation, and Individualized Consideration); transactional leadership style (Contingent Reward, and Management-by-exception); and Hofstede cultural values (power distance, uncertainty avoidance, and individualism vs collectivism) show satisfactory internal consistency for those variables. The reliability scores of all scales (Cronbach Alpha) exceed 0.90, which is more than the cut-off level of 0.7 recommended by Nunnally and Bernstein (1994). Moreover, the Corrected Item - Total Correlation (CITC) was employed as an indicator of internal consistency within variables' which shows the level of correlation between each variable and the total score. CITC was employed to assess whether all scales established a dominant loading on the supposed factor and did not have any significant cross-loadings. The results of CITC ranged from 0.587 to 0.930 . These results are satisfactory and are more than the cut-off value of 0.4 recommended by Nunnally and Bernstein (1994).

\section{SEM Results and Interpretations}

An average composite score for each dimension employed in the current study was used to draw the path analysis in structural equation modeling as shown in figure (2). Structural equation modeling was used in the current research as the main data analysis technique. SEM can test the causal relationships between 
among the research dimensions (Byrne, 2010). Additionally, SEM is a method to test multiple and interrelated associations between the variables to make a model. It is the only technique that permits complete and simultaneous data analysis of all relationships for the multidimensional model structure (Tabachnic and Fidell, 2007).

Several goodness-of-fit (GOF) measures were employed to assess model fit as shown in table (4). The model was specified and over identified; the data for the models was analysis by using AMOS v18 and the ML estimation technique.

Table 4: Goodness of fit indices

\begin{tabular}{|c|c|c|}
\hline GOF statistics & Obtained value & Reference value \\
\hline Normed $x^{2}$ & 1.836 & $<3.00$ \\
CFI & .995 & CFI $\geq 0.90$ \\
\hline $\begin{array}{c}\text { NFI } \\
\text { Normed Fit Index }\end{array}$ & .990 & NFI $\geq 0.90$ \\
\hline $\begin{array}{c}\text { IFI } \\
\text { Incremental Fit Index }\end{array}$ & .995 & IFI $\geq 0.90$ \\
\hline $\begin{array}{c}\text { AGFI } \\
\text { Adjusted Goodness-of-Fit } \\
\text { Index }\end{array}$ & .959 & PNFI $\geq 0.90$ \\
\hline $\begin{array}{c}\text { GFI } \\
\text { Goodness-of-Fit Index }\end{array}$ & .999 & PCFI $\geq 0.90$ \\
\hline $\begin{array}{c}\text { RMSEA } \\
\text { Root Mean Square Error } \\
\text { of Approximation }\end{array}$ & .046 & RMSEA $\leq .05$ \\
\hline
\end{tabular}

Source: Adopted from Tabachnic and Fidell (2006); Byrne (2010); Schumacker and Lomax (2010); and Hair et al., (2006)

The goodness of fit indices (GOF), as shown in table (4), indicate that the study model fits the data well. More specific, Normed $\chi^{2}=1.836$ (below the cut of point of 3), RMSEA $=0.046$ (below the cut of point of .05 ), $\mathrm{CFI}=0.995$, NFI=0.990, $\mathrm{IFI}=0.995$ (all above the cut of point of .90 ), GFI=0.999, and AGFI=0.959 (both above the cut of point of .90), (see table 4).

After attaining satisfactory indices for the current study model, the research hypotheses were tested. Each path in the model as shown in figure (2) represents a specific hypothesis. Table 5 contains selected output from AMOSv18 showing the research hypotheses, unstandardized (estimates) regression weights (Un-Stand. Est.), standardized (estimates) regression weights (Stand. Est.), standard error (S.E), the critical ratio (CR), and the P-value. The SEM results indicate six positive significant relationships and six insignificant negative relationships. More specific, the investigation of the path coefficients and its related P-value to test the impact of high power distance on transactional leadership style reveals that employees with high power distance have a direct positive effect (i.e. prefer) on the transactional leadership style $(0.32 ; \mathrm{P}<0.05)$, relatively employees with high power distance have a negative insignificant impact on (in other words, do not prefer) the transformational leadership style $(-0.083 ; \mathrm{P}=0.928)$.

This result indicates that when employees don't question the choices of their managers and are afraid of any potential conflict, and when their relationship with managers are not close, expect to have their responsibilities and jobs commanded to them, and in some cases, will not show disagreement with their managers, the best leadership style for them is the transactional leadership style (i.e tell employees what to do to meet the standardized job criteria in order to be rewarded). This result is consistent with previous studies such as Dvir et al. (2002). 
Table (5): AMOS output: Regression Weights, standard error, critical ratio, and p-value

\begin{tabular}{|c|c|c|c|c|c|c|c|}
\hline \multicolumn{2}{|c|}{ Study Relationships } & $\begin{array}{c}\text { Stand. } \\
\text { Est. }\end{array}$ & $\begin{array}{c}\text { Un. } \\
\text { Est. }\end{array}$ & S.E. & C.R. & P \\
\hline TRANSFORMATIONAL & $<---$ & HIGHPOW & -.083 & .007 & .075 & .091 & .928 \\
\hline TRANSACTIONAL & $<---$ & HIGHPOW & .323 & .391 & .169 & 2.316 & .021 \\
\hline TRANSFORMATIONAL & $<--$ & LOWPOW & .384 & .447 & .176 & 2.541 & .011 \\
\hline TRANSACTIONAL & $<---$ & LOWPOW & -.079 & -.081 & .056 & -1.440 & .150 \\
\hline TRANSFORMATIONAL & $<---$ & HIGHUNCERT & -.190 & -.291 & .400 & -.727 & .467 \\
\hline TRANSACTIONAL & $<--$ & HIGHUNCERT & .331 & .331 & .167 & 1.977 & .048 \\
\hline TRANSFORMATIONAL & $<---$ & LOWUNCERT & .570 & .423 & .045 & 9.367 & $* * *$ \\
\hline TRANSACTIONAL & $<---$ & LOWUNCERT & -.083 & -.097 & .059 & -1.650 & .099 \\
\hline TRANSFORMATIONAL & $<---$ & INDIVIDUALISM & -.031 & -.030 & .051 & -.592 & .554 \\
\hline TRANSACTIONAL & $<---$ & INDIVIDUALISM & .22 & .228 & .075 & 3.062 & .002 \\
\hline TRANSFORMATIONAL & $<--$ & COLLECTIVISM & .194 & .228 & .066 & 3.451 & $* * *$ \\
\hline TRANSACTIONAL & $<--$ & COLLECTIVISM & -.163 & -.186 & .257 & -.724 & .469 \\
\hline
\end{tabular}

Similarly, low power distance employees were found to have a direct positive significant effect on (in other words, prefer) the transformational leadership style $(0.38 ; \mathrm{P}<0.05)$ rather than transactional leadership style $(-0.079 ; \mathrm{P}=0.150)$. This result indicates that when most of the hotel employees can be considered equal, or nearly equal in skills and payment (narrow compensation range from bottom to top), and employees expect to be consulted and empowered, in this case, the transformational leadership style (i.e. Motivating followers to act beyond expectations by communicating them the importance of tasks outcomes, this makes them transcend their self-interest for the sake of the property) is the best leadership style for the low power distance employees. Again this result is consistent with previous studies like Dvir et al. (2002). 


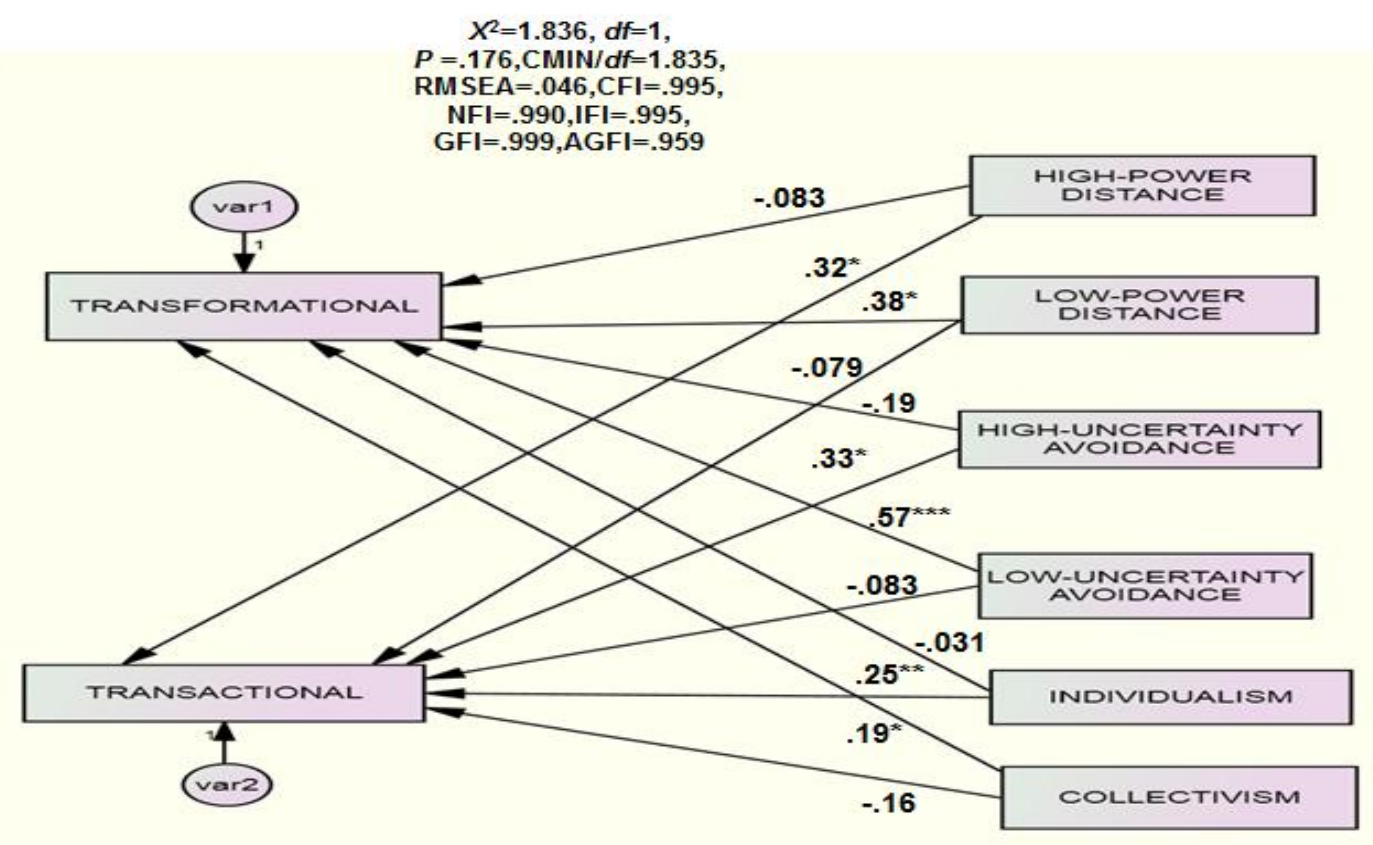

Figure (2): The proposed research model

\section{***Correlation is significant at the 0.00 level; ** Correlation is significant at the 0.01 level; * Correlation is significant at the $\mathbf{0 . 0 5}$ level}

The SEM results show also a positive significant impact of high uncertainty avoidance employees on the transactional leadership style $(0.33 ; \mathrm{P}<0.05)$ rather than transformational style $(-0.190 ; \mathrm{P}=0.467)$. This result indicates that when employees prefer task-oriented leadership that includes giving explicit directions and reducing vagueness regarding job assignments, the best leadership style is the transactional leadership style (Den Hartog et al., 1999). Likewise, low uncertainty avoidance employees were found to have a positive significant impact on the transformational leadership style $(0.57 ; \mathrm{P}<0.001)$ rather than transactional style ($0.083 ; \mathrm{P}=0.099)$. This result indicates that when employees have more flexibility and choices in the job, the transformational leadership style is the best match them. This result is consistent with previous studies such as Shane et al. (1995)

Additionally, the results give an evidence that individualism cultural value has a positive impact on the transactional leadership style $(0.25 ; \mathrm{P}<0.05)$ and a negative impact on transformational leadership style $(-0.031 ; \mathrm{P}=0.554)$, while collectivism cultural value has a positive direct impact on the transformational leadership style $(0.19 ; \mathrm{P}<0.05)$ and a negative insignificant direct impact on the transactional leadership style $(-0.163 ; \mathrm{P}=0.469)$. This results infer that when employees place a great emphasis on individual initiative, rights, and achievement (individualism), the best leadership style is the transactional leadership style, while when employees form a tight social framework where people differentiate between in-groups and out-groups and provide loyalty to in-groups expecting support from them (collectivism), the best leadership style is the transformational leadership style. These results are consistent with previous studies such as Jung and Avolio (1999).

\section{Conclusion}

For achieving leader-follower value congruence, this study investigated the impact of employees' cultural values (power distance, uncertainty avoidance, and individualism vs. collectivism) on the appropriate leadership style (transactional and transformational leadership style); to date and to authors' knowledge; this is the first study that theoretically and empirically tests such relationships within the hospitality industry in Egypt. The data was obtained from 400 employees in five-star hotels and analyzed by using path analysis in structure equation modeling. The results give evidence that employees with high power distance value (i.e. afraid of any potential conflict, and no close relationship with manager); high uncertainty avoidance (i.e. giving explicit directions and reducing vagueness regarding job assignments); and individualism (i.e. employees place a great emphasis on individual initiative, rights, and achievement), the leadership style that 
best fits them is the transactional leadership style (i.e. tell employees what to do to meet the standardized job criteria in order to be rewarded). The results also show that employees with low power distance value (i.e. employees expected to be consulted and empowered); low uncertainty avoidance (i.e. employees have more flexibility and choices in the job); and collectivism (i.e. when employees differentiate between in-groups and out-groups and provide loyalty to in-groups expecting support from them), the leadership style that best fits them is the transformational leadership style (i.e. Motivating followers to act beyond expectations by communicating them the importance of tasks outcomes). To conclude, a manager who has the transactional characteristics without having the transformational leadership style can be considered a mediocre leader. On the other hand, someone who is a good transformational leader can shift the followers' current values to the new values recommended by their leaders. Finally, we suggest that both leadership styles (transactional and transformational) can simultaneously co-exist in one leader to lead his followers with different values and that these joining impacts of both transactional and transformational leadership style should be complementary instead of contradictory.

\section{Limitations and future research}

The current research paper suffered from limitations very common to SEM and survey research. The survey research conducted in this study, like in most papers in this area, is a cross-sectional sample at a precise one point in time. As a result, while causal associations can be inferred, they cannot be accurately confirmed (Bullock et al, 1994). The suggested model can be duplicated in other contexts (industry and / or country) to confirm/reject the current study results. It's worth noting that the investigated cultural values in the current study are the most regularly and widely tested and validated in the literature review, however there are other cultural values that were not investigated in this paper such as Masculinity vs. femininity, Long-term orientation vs. short-term orientation, and Indulgence vs. restraint. Therefore it's advisable to further research the relationship between these uncovered cultural values and leadership style.

\section{References}

- Adler, N. J. and Gundersen, A. (2008). International dimensions of organizational behavior. $5^{\text {th }}$ Ed. Ohio: South-Western.

- Bass, B.M. (1985). Leadership and performance beyond expectations. New York, NY: Free press.

- Bass, B.M. (2000). The future of leadership in learning organizations. The Journal of Leadership Studies, 7 (3), 18-40.

- Bass, B.M.; Avolio, B.J.; Jung, D.I. and Berson, Y. (2003). Predicting unit performance by assessing transformational and transactional leadership. Journal of Applied Psychology, 88 (2), 207-218.

- Bass, B.M and Riggio, R.E. (2006). Transformational leadership. 2nd Ed. New Jersey: Lawrence Erlbaum Associates, Inc.

- Bullock, Heather R.; Harlow, Lisa L. and Mulaik, Stanley A. (1994). Causation issues in structural equation modeling research. Structural Equation Modeling, 1, 253-267.

- Burns, J.M. (1978). Leadership. New York, NY: Harper and Row.

- Byrne, B. (2010). Structural equation modelling: Basic concepts, applications, and programming. London: Lawrence Erlbaum Associates.

- Cullen, J.B. and Parboteeah, K.P. (2005). Multinational Management: A Strategic Theory. $3^{\text {rd }}$ Ed. Ohio: South Western - Thomson Learning.

- Den Hartog, D.N.; House, R.J.; Hanges, P.J.; Ruiz-Quintanilla, S.A.; Dorfman, P.W. and GLOBE Associates (1999). Culture specific and cross-culturally generalizable implicit leadership theories: Are attributes of charismatic/transformational leadership universally endorsed?. In Dickson, M.W., Den Hartog, D.N. and Mitchelson, J.K. (2003). Research on leadership in a cross-cultural context: Making progress, and raising new questions. The Leadership Quarterly, 14, 729-768.

- Dvir, T.; Eden, D.; Avolio, B.J. and Shamir, B. (2002). Impact of transformational leadership on follower development and performance: a field experiment. Academy of Management Journal, 45 (4), 735-744.

- Edwards, J. R. and Cable, D. M. (2009). The value of value congruence. Journal of Applied Psychology, 94, 654677.

- Erkutlu, H.V. and Chafra, J. (2006). Relationship between leadership power bases and job stress of followers: Example from boutique hotels. Management Research News, 29 (5), 285-297. 
- Field, A. (2006). Discovering statistics using SPSS ( $2^{\text {nd }}$ Ed.). London: Sage.

- George, J.M. and Jones, G.R. (2008). Understanding and Managing Organizational Behavior. $5^{\text {th }}$ Ed. New Jersey: Pearson Education Inc.

- Gill, A.S.; Flaschner, A.B. and Shacha, M. (2006), "Mitigating stress and burnout by implementing transformational-leadership", International Journal of Contemporary Hospitality Management, 18 (6), 469481.

- Griffin, R.W. (2000). Griffin's fundamentals of management: Core concepts and applications. $5^{\text {th }}$ Ed. Boston Massachusetts: Houghton Mifflin Company.

- Hair, J.; Black, B.; Babin, B.; Ralph, A. and Ronald, T. (2006). Multivariate data analysis (6 ${ }^{\text {th }}$ Ed.). London: Prentice-Hall.

- Hofstede, G. (1980). Motivation, Leadership, and Organization: Do American Theories Apply Abroad?. Organizational Dynamics, Summer, AMACOM / American Management Association, 42-63.

- Hofstede, G. (1991). Culture and organizations: Software of the mind. London: McGraw-Hill.

- Jackson, T. (2011). From cultural values to cross-cultural interfaces: Hofstede goes to Africa. Journal of Organizational Change, 24 (4), 532-558.

- Johns, G. and Saks, A.M. (2005). Organizational Behaviour: understanding and Managing Life at Work. $6^{\text {th }}$ Ed. Ontario: Pearson Education Inc.

- Jones, G.R. and George, J.M. (2007). Essentials of Contemporary Management. $2^{\text {nd }}$ Ed. New York, NY: McGraw-Hill/Irwin.

- Jones, G.R. (2004). Organizational theory, design, and change: Texts and cases. $4^{\text {th }}$ Ed. New Delhi: Pearson Education Inc.

- Jung, D.I. and Avolio, B.J. (1999). Effects of leadership style and followers' cultural orientation on performance in group and individual task condition. Academy of management Journal, 42 (2), 208-218.

- Jung, D. I. and Avolio, B. J. (2000). Opening the black box: An experimental investigation of the mediating effects of trust and value congruence on transformational and transactional leadership. Journal of Organizational Behavior, 21(8), 949-967.

- Kalliath, T.J.; Bluedom, A.C. and Strube, M.J. (1999). A test of value congruence effects. Journal of Organizational Behavior, 20 (7), 1175-1198.

- Kouzes, J.M. and Posner, B.Z. (2003). The leadership challenge workbook. $1^{\text {st }}$ Ed. San Francisco: JosseyBass.

- Luthans, F. and Doh, J.P. (2009) International management. $7^{\text {th }}$ Ed. New York, NY: McGraw-Hill companies Inc.

- Meglino, B. M.; Ravlin, E. C. and Adkinsm C. L. (1991). Value congruence and satisfaction with leader: An examination of the role of interaction. Human Relations, 44 (5), 481-496.

- Moorhead, G. and Griffin, R.W. (1992) Organizational behavior: Managing people and organizations. $3^{\text {rd }}$ Ed. Boston: Houghton Mifflin Company.

- Mullins, L.J. (2006). Essentials of Organisational Behaviour. Essex: Pearson Education Ltd.

- Newman, K.L., Nollen, S.D. (1996). Culture and congruence: the fit between management practices and national culture. Journal of International Business, 27 (4), 753-779.

- Nunnally, J. and Bernstein, I. (1994). Psychometric theory ( $3^{\text {rd }}$ Ed.). New York: McGraw-Hill.

- Riketta, M. (2005). Organizational identification: A meta-analysis. Journal of Vocational Behavior, 66, 358-384

-Robbins, S.P. and DeCenzo, D.A. (2004). Fundamentals of management: Essentials, concepts and applications. $4^{\text {th }}$ Ed. New Jersey: Pearson Education Inc.

- Sarros, J.C. and Santora, J.C. (2001). The transformational-transactional leadership model in practice. Leadership and Organization Development Journal, 22 (8), 383-393.

- Schumacker, R. and Lomax, R. (2010). A beginner's guide to structural equation modelling. London: The University of Alabama

- Shahin, A. and Wright, P. (2004). Leadership in the context of culture: An Egyptian perspective. Leadership \& Organization Development Journal, 25 (6), 499-511. 
- Shane, S.A.; Venkataraman, S. and MacMillan, I. (1995). Cultural differences in innovation championing roles. Journal of Management, 21, 931-952.

- Sinha, J. B. P. (2008). Culture and organizational behavior. New Delhi: Sage Publications.

- Strogh, L.K.; Northcraft, G.B. and Neale, M. A. (2002). Organizational Behavior: A management challenge. $3^{\text {rd }}$ Ed. New Jersey: Lawrence Erlbaum Associates Inc.

- Tabachnick, B., and Fidell, L. (2007). Using multivariate statistics (5 ${ }^{\text {th }}$ Ed.). New York, NY: Pearson Education.

- Tsai, C. (2008). Leadership style and employee's job satisfaction in international tourist hotels. Advances in Culture, Tourism and Hospitality Research, 2, 293-332.

- Yu, H. and Miller, P. (2005). Leadership style: The X generation and baby boomers compared in different cultural contexts. Leadership \& Organization Development Journal, 26 (1), 35 - 50

- Yukl, G. (2010). Leadership in organizations. $7^{\text {th }}$ Ed. New Jersey: Prentice Hall.

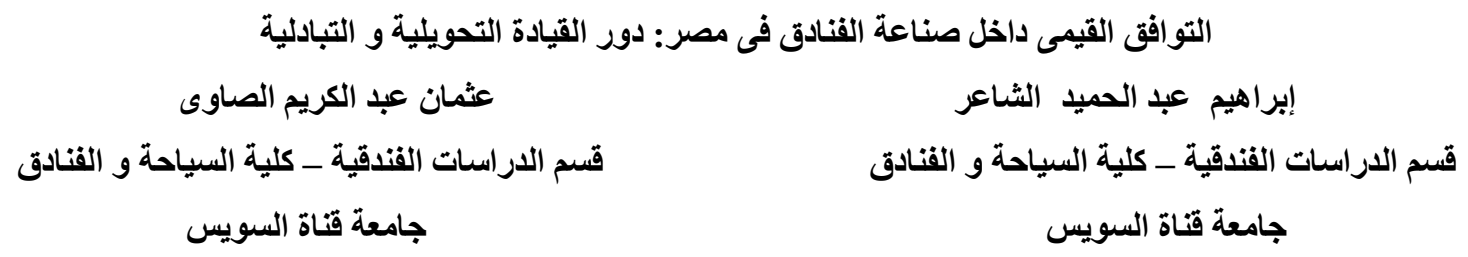

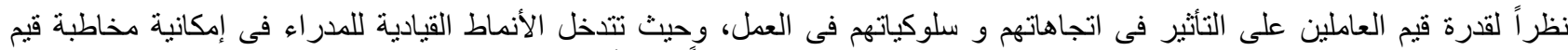

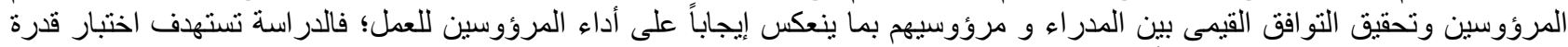

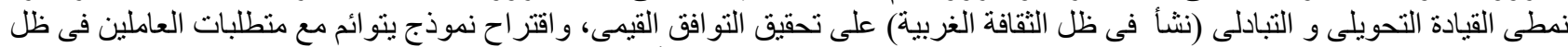

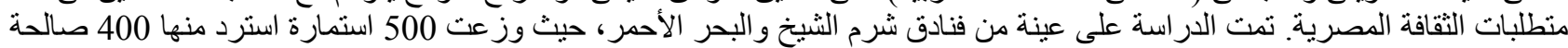
للتحليل الاحصائى وتم تحليل البيانات بإستخدام تحليل المسار (

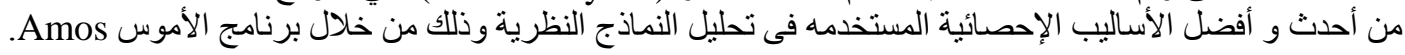

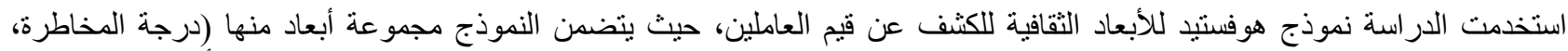

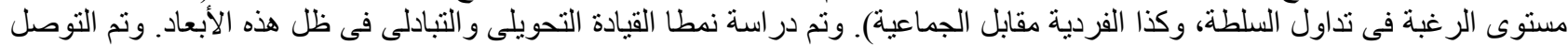
لنموذج يحدد النمط القيادى الأمثل للعاملين على اختلاف قيمهم الثقافية، بما يمكن الفنادق المصرية من تحقيق مفهوم التو افق القيمى داخلها. 